https://doi.org/10.11646/zootaxa.4281.1.21

http://zoobank.org/urn:Isid:zoobank.org:pub:E4C28268-1935-410B-9B2B-5F3CB8C0ABE4

\title{
A new species of Rhabdotalebra Young (Hemiptera: Cicadellidae: Typhlocybinae) associated with the guaran-guaran (Bignoniaceae: Tecoma stans L.) in Argentina
}

\author{
SUSANA PARADELL ${ }^{1,4}$, MARÍA INÉS CATALANO ${ }^{2} \&$ JULIÁN PETRULEVIČIUS ${ }^{3}$ \\ ${ }^{I}$ Investigador CIC. Universidad Nacional de La Plata. División Entomología. Facultad de Ciencias Naturales y Museo. La Plata, \\ Buenos Aires, Argentina. E-mail: paradell@fcnym.unlp.edu.ar \\ ${ }_{2}^{2}$ Investigador CIC. Universidad Nacional del Noroeste de la Provincia de Buenos Aires, Centro de Bioinvestigaciones, Pergamino, \\ Buenos Aires, Argentina.E-mail: mariainescatalano@gmail.com \\ ${ }^{3}$ Investigador CONICET. Universidad Nacional de La Plata. División Paleozoología Invertebrados. Facultad de Ciencias Naturales y \\ Museo, La Plata,Buenos Aires, Argentina.E-mail: levicius@fcnym.unlp.edu.ar \\ ${ }^{4}$ Corresponding author. E-mail: paradell@fcnym.unlp.edu.ar
}

\begin{abstract}
The genus Rhabdotalebra Young is reviewed, including description of a new species, R. albinoi n. sp., from Buenos Aires province, Argentina. A detailed morphological description and illustrations of the new species are provided. A key of all known Rhabdotalebra species is provided to facilitate the comparison of the new species with those previously known, based on pattern coloration and male and female genitalia, is given. Some field observations on its biology are also provided.
\end{abstract}

Key words: Auchenorrhyncha, morphology, taxonomy, distribution

\section{Introduction}

The cicadellid subfamily Typhlocybinae is a large group comprising 450 genera and $>5000$ species of mostly small, delicate leafhoppers Dietrich (2013). Aproximately, 900 species are recorded from the Neotropical region (Oman et al. 1990), including 14 genera and 69 species in Argentina Catalano (2011).

The Neotropical genus Rhabdotalebra (Alebrini) established by Young (1952) with Protalebra octolineata Baker, 1903 as type also includes the following ten species: R. brunnea (Oman, 1937); R. hambletoni Young, 1957; $R$. signata (McAtee, 1926); $R$. jamaicensis Young, 1957; $R$. monrosi Young, 1957; $R$. ornata Young, 1957; $R$. plummeri (Ruppel \& DeLong, 1953); R. pikna Dworakowska, 1994; R. litoralensis Catalano, 2010 and $R$. flava Catalano, 2010. The latter two were described and illustrated by Catalano et al. (2010). The species from Argentina are mainly distributed in the northern areas, Northeast Argentina NEA and Northwest Argentina NOA (Jujuy, Tucumán and Entre Ríos provinces), associated with "lapachos" trees: Tabebuia pulcherrima Sandw. ("lapacho amarillo"); Tabebuia impetiginosa (Mart. ex DC.) Standley and Tabebuia ipe (Mart.) Standley ("lapachillo"). The genus Tabebuia Gomes ex DC. (Bignoniaceae) comprises one hundred native species in tropical America, extending from Mexico and the Caribbean to Argentina (Misiones, Corrientes, Chaco, Formosa, Entre Rios and Tucumán), Brazil from South Central to Amazon, and also in low-lying areas in southern Paraguay, Bolivia and Peru in some mountain areas Alonso (2000).

Here we describe and illustrate a new species, R. albinoi n. sp., from Argentina, associated with Tecoma stans (Linnaeus) Juss. ex Kunth (Bignoniaceae) ("Guarán-Guarán" or yellow trumpetbush). "Guarán-Guarán" is distributed from southern United States to Argentina and is an ornamental tree. Discovery of the new species extends the known range of the genus to Buenos Aires province, La Plata and Temperley cities, the southernmost records of Rhabdotalebra.

Geographical distribution, host plants and some field observations on its biology are recorded. In addition, a 
key to identify Rhabdotalebra species is given, modified from Young (1957) and Catalano et al. (2010) based on color pattern and male and female genitalia.

\section{Materials and methods}

Adults of the new species were collected on leaves of Tecoma stans with manual aspirators during autumn and

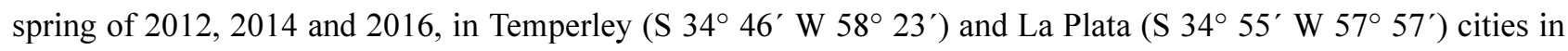
Buenos Aires province, Argentina. Adults were present throughout the year. For morphological study of the genital structures, clearing was accomplished by immersion of the entire abdomen in a solution of $10 \% \mathrm{KOH}$ at room temperature. Specimens were prepared for microscopic examination according to standard techniques, were drawn using a stereoscopic microscope with a camera lucida. The colour pattern here described is the post-mortem coloration. Photographs were taken with a digital camera attached to a Zeiss microscope and digital images were assembled using Combine ZM open software (Hadley 2011). Damaged recent leaves of T. stans and the leafhoppers producing the stippling were collected on May 15, 2012 at La Plata. The photograph of the whole leaf (Fig. 3A) was taken just after collection with a Nikon D5000 camera (Petrulevičius et al. 2014). The morphological terminology follows Balduf (1934), Young (1952), Southern (1982), Dietrich (2005) and Catalano et al. (2010). A check list of all Argentinian species of the genus with information about distribution and host plants is included. Some field observations on biology are given. The type of the described species and other specimens examined are housed in the entomological collection of the Museo de Ciencias Naturales de La Plata (MLP) La Plata, Argentina.

\section{Results}

\section{Rhabdotalebra Young 1952}

Type species: Protalebra octolineata Baker, 1903, by original designation.

Morphological diagnoses of Rhabdotalebra were provided by Young (1957) and Catalano et al. (2010).

Host plants: (Bignonaceae) Tabebuia pulcherrima Sandw; Tabebuia impetiginosa (Mart. ex DC.) Standley ("lapachos"), Tabebuia ipe (Mart.) Standley ("lapachillo") (Catalano et al. 2010), Tecoma stans (Linnaeus) Juss. ex Kunth (Guarán-Guarán).

Geographical distribution: Species of the genus distributed in Argentina were previously recorded from the northern provinces (Young 1957; Catalano 2010). The new finding represents the southernmost distribution of the genus.

\section{Rhabdotalebra species from Argentina}

R. flava Catalano, 2010. Distribution: Argentina: Tucumán (Catalano et al. 2010).

Host Plants: Tabebuia pulcherrima Sandw. ("Lapacho amarillo") and T. ipe (Mart.) Standley ("lapachillo") (Catalano et al. 2010).

R. hambletoni Young, 1957. Distribution: Argentina: Jujuy (Dworakowska 1994)

Host Plants: unknown.

R. litoralensis Catalano, 2010. Distribution: Argentina: Entre Ríos, Concordia Catalano et al. (2010).

Host Plants: Tabebuia impetiginosa ("Lapacho Rosado") (Catalano et al. 2010).

R. monrosi Young, 1957. Distribution: Argentina: Jujuy, Ledesma (Young 1957). Hosts Plants: unknown.

R. albinoi n. sp. Distribution: Argentina. Buenos Aires, La Plata, Temperley. Host Plants: Tecoma stans (L.) Juss. ex Kunth (Guarán-Guarán). 


\section{Key to the species of the genus Rhabdotalebra Young (adapted from Catalano et al. 2010 to include $R$. albinoi n.sp.)}

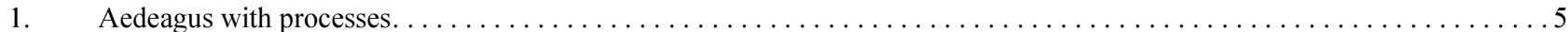

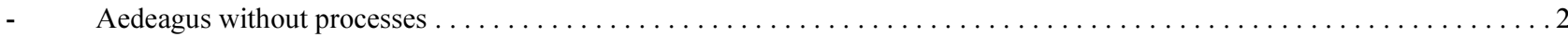

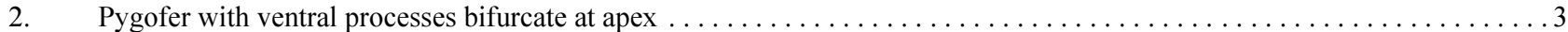

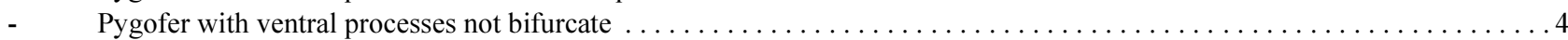

3. Aedeagal shaft with very broad base and narrow apex with two pairs of anteapical teeth (Young, 1957: Fig. 29d, p. 234). Ster-

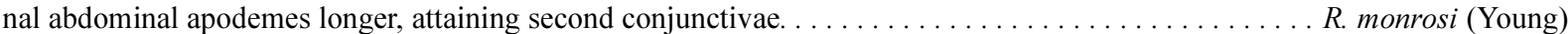
Aedeagal shaft slender without teeth (Young, 1957: Fig. 28, p. 230). Sternal abdominal apodemes shorter, not attaining first

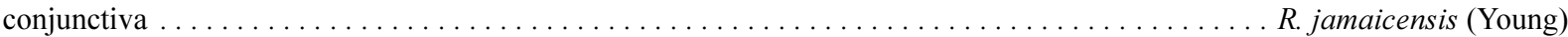

4. Aedeagal shaft abruptly narrowed in apical third. Sternal abdominal apodemes longer, attaining second conjunctivae (Young, 1957: Fig. 28, p. 230). Female seventh sternum slightly convex . . . . . . . . . . . . . . . . . . . R. signata (McAtee) Aedeagal shaft gradually tapering (Young, 1957: Fig. 28, p. 230). Sternal abdominal apodemes shorter, not attaining first con-

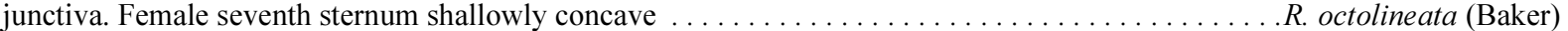

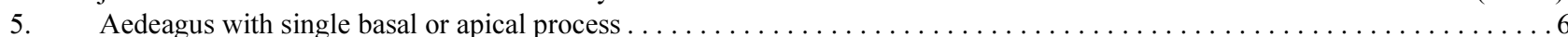

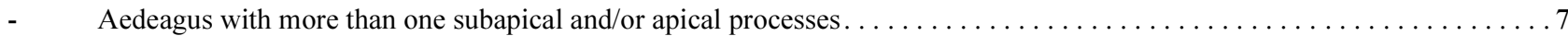

6. Aedeagus with apical process directed ventrocaudally. Pygofer with shorter ventral process. Connective U-shaped. Sternal abdominal apodemes attaining first conjunctiva. Female seventh sternum with rounded median lobe (Catalano et al. 2010: Fig. 1 p. 56) R. litoralensis Catalano Aedeagus with basal process directed dorsally. Pygofer with long ventral process. Connective transverse bar shaped. Sternal abdominal apodemes not attaining first conjunctivae. Female seventh sternum with posterior margin slightly concave (Catalano et al. 2010: Fig. 2 p. 58)

R. flava Catalano

7. Pygofer process absent. Connective U-shaped. Aedeagus processes dorsal and symmetrical (Young, 1957: Fig. 29, p. 234). Forewing with hourglass-shaped white commissural marking . . . . . . . . . . . . . . . R. plummeri (Ruppel \& DeLong) Pygofer with processes. Aedeagus with processes lateral, ventral or asymmetrical. $\ldots \ldots \ldots \ldots \ldots \ldots \ldots \ldots \ldots$

8. Pygofer with processes (occasionally not differentially sclerotized). Connective bar shaped. Aedeagus processes ventral or lat-

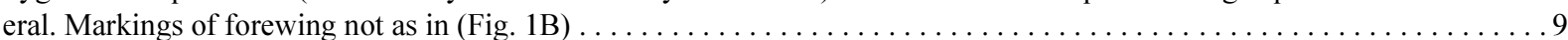
Pygofer with subapical processes strongly esclerotized, curved on the ventral margin (Fig. 1D). Conective U-sharped. Aedeagus with subapical and apical processes asymmetrical, directed caudoventrally (Fig. 1G). Color pattern of the forewings as in Fig. 1B. Female seventh sternum with posterior margin with short rounded median lobe (Fig.2A) . . . . . . R. albinoi n. sp.

9. Aedeagus processes recurved laterally. Gonopore terminal (Young, 1957: Fig. 29, p. 234). Dorsum marked with inverted 'T" extending over pronotum, scutellum and basal half of forewings $\ldots \ldots \ldots \ldots \ldots \ldots \ldots \ldots$. $\ldots \ldots$ hambletoni (Young) Aedeagus processes otherwise. Gonopore subapical. Markings of dorsum otherwise $\ldots \ldots \ldots \ldots \ldots \ldots \ldots \ldots \ldots \ldots$

10. Aedeagus processes apressed to shaft (Young, 1957: Fig. 30, p. 239). Sternal abdominal apodemes shorter, attaining first con-

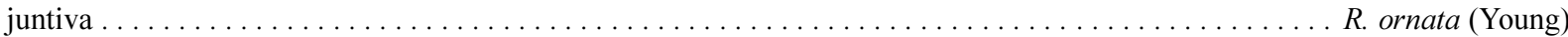
Aedeagal process extending laterad, not appressed to shaft. Sternal abdominal apodemes longer, attaining second or third conjunctivae (Young, 1957: Fig. 30, p. 239). R.brunnea (Oman)

\section{New species}

\section{Rhabdotalebra albinoi Paradell \& Catalano, n. sp.}

(Figs. 1A-G, 2 A-D, 3A)

Description. Length: 2.8-2.9 mm. Coloration yellowish with distinctive brown dark marks on forewings (Fig. 1A). Crown produced with apex rounded; posterior margin regularly concave. Pronotum median length 0,5 times greater than median length of crown; lateral margins divergent posteriorly (Fig. 1A).

Fore and hind wing venation characteristic of genus. Forewings with pattern similar to but darker than in $R$. litoralensis. Brown mark in basal half involving both clavus and corium crossing transversely to commissural vein, reaching costal vein; transverse vitta near base of vein $\mathrm{R}$; rhomboidal mark dark brown from vein $\mathrm{R}$ to inner apical cell, darker brown blotch in outer apical cell, apical portions of all apical cells smoky, outer cell darker (Fig.1B).

Male: First sternal complex (1S) (Fig.1C) with sternal bar thin and straight ventrally; dorsal apodeme well developed, medial notch not reaching sternal bar; lateral apodeme well developed, extending dorsally. Second sternal abdominal apodeme (2S) (Fig.1C) short, reaching third segment, medial margins concave, apex rounded. Pygofer (Fig.1D) subtriangular in lateral view, with uniseriate group of four to six macrosetae on dorsoposterior margin, few microsetae dispersed on disk; with ventral strongly sclerotized subapical process (Fig.1E) curved on ventral margin, extended to pygofer apex, apex with bifurcate, divergent, strongly sclerotized and prominent dark spines on posterodorsal margin, one longer than other. Subgenital plate (Fig.1F) elongated, triangular, abruptly 

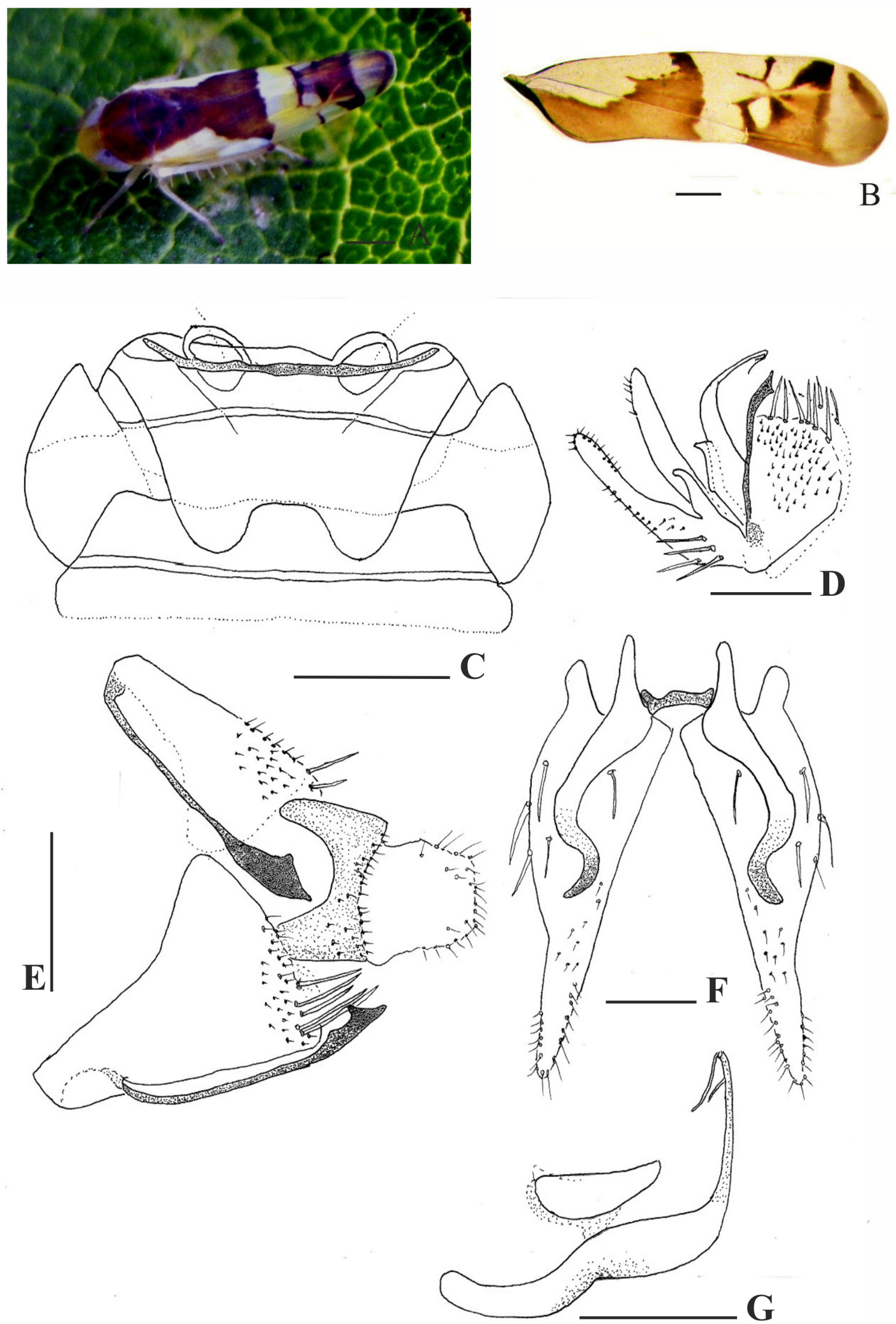

FIGURE 1. A-G. Rhabdotalebra albinoi n.sp. A, dorsal habitus; B, forewing. Male: C-G. C, sternal apodeme (1S, 2S); D, genital capsule; E, pygofer, lateral view and anal tube; F, subgenital plate, style, connective; G, aedeagus, lateral view. Scale bar $=($ Figs. A-B: 3mm; C-G: 0.2mm; F: 0.1mm). 
narrowed near midlength, exceeding ventral pygofer process, with three macrosetae confined on disk to half basal, one row of short and strong setae extended from midlength to apex. Style (Fig.1F) short and robust, with conspicuous and rounded preapical lobe; apical extension strongly sclerotized and abruptly curved caudoventrad, apex rounded. Connective (Fig.1F) small, shallowly U-shaped. Aedeagus (Fig.1G) in lateral view with preatrium distinct; dorsal apodeme well developed, saddle-shaped in lateral aspect, bilobed at base; shaft slender, curved dorsad, with one subapical process short, divergent from shaft in lateral view, and one apical processes long and sinuous directed ventrocaudally, reaching shaft midlength, apex acuminate; gonopore apical. Anal tube (Fig.1E) with lateral margins weakly sclerotized.

Female: Length: $3.0-3.1 \mathrm{~mm}$. Shape and general coloration very similar to those of male.
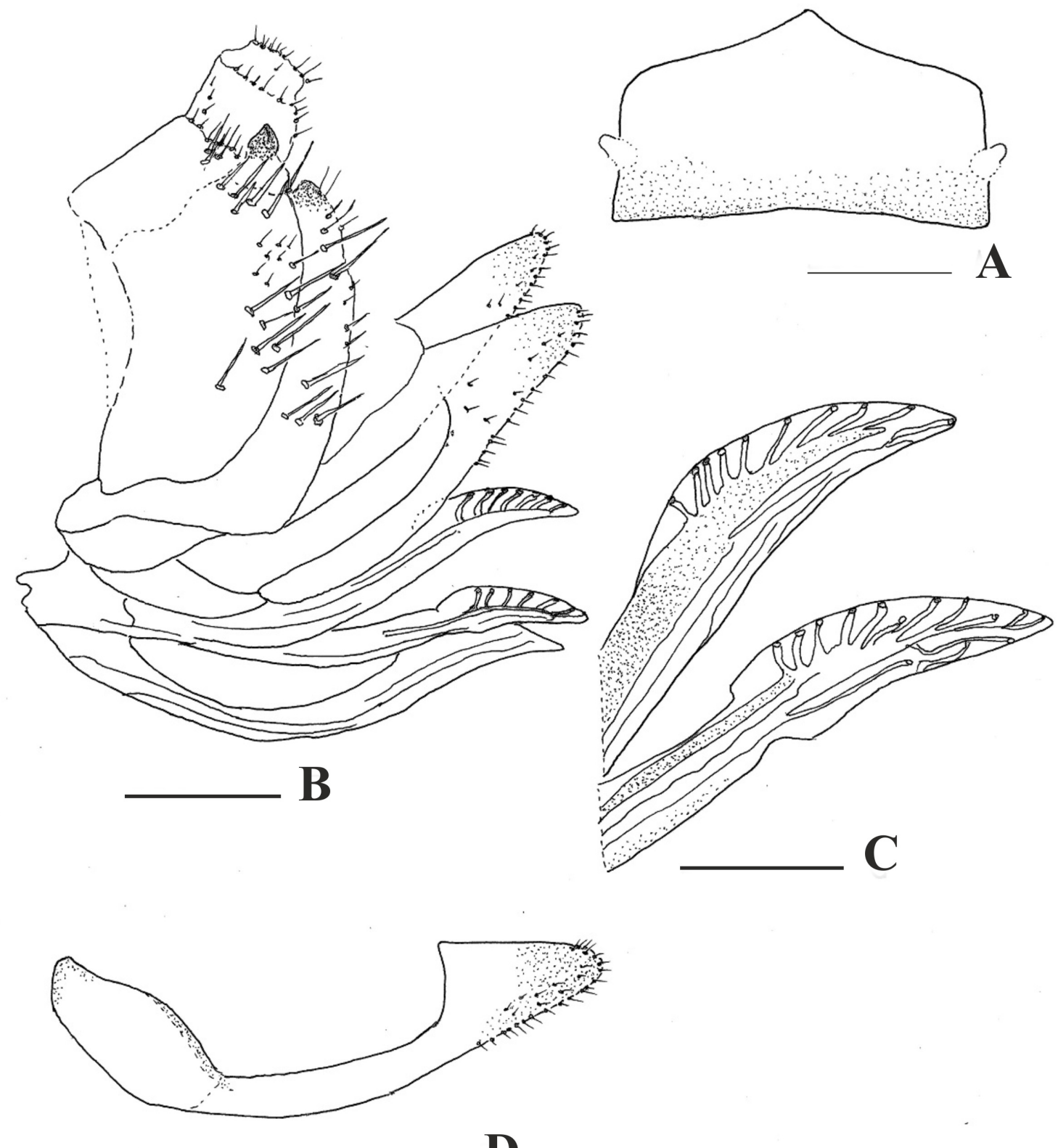

FIGURE 2. A-D. Rhabdotalebra albinoi n.sp. Female: A-D. A, sternite VII; B, genital capsule, lateral view; C, large valve, small valve; D, third valve. Scale bar= (Figs. A-D: $0.2 \mathrm{~mm}$; B: $0.25 \mathrm{~mm})$. 


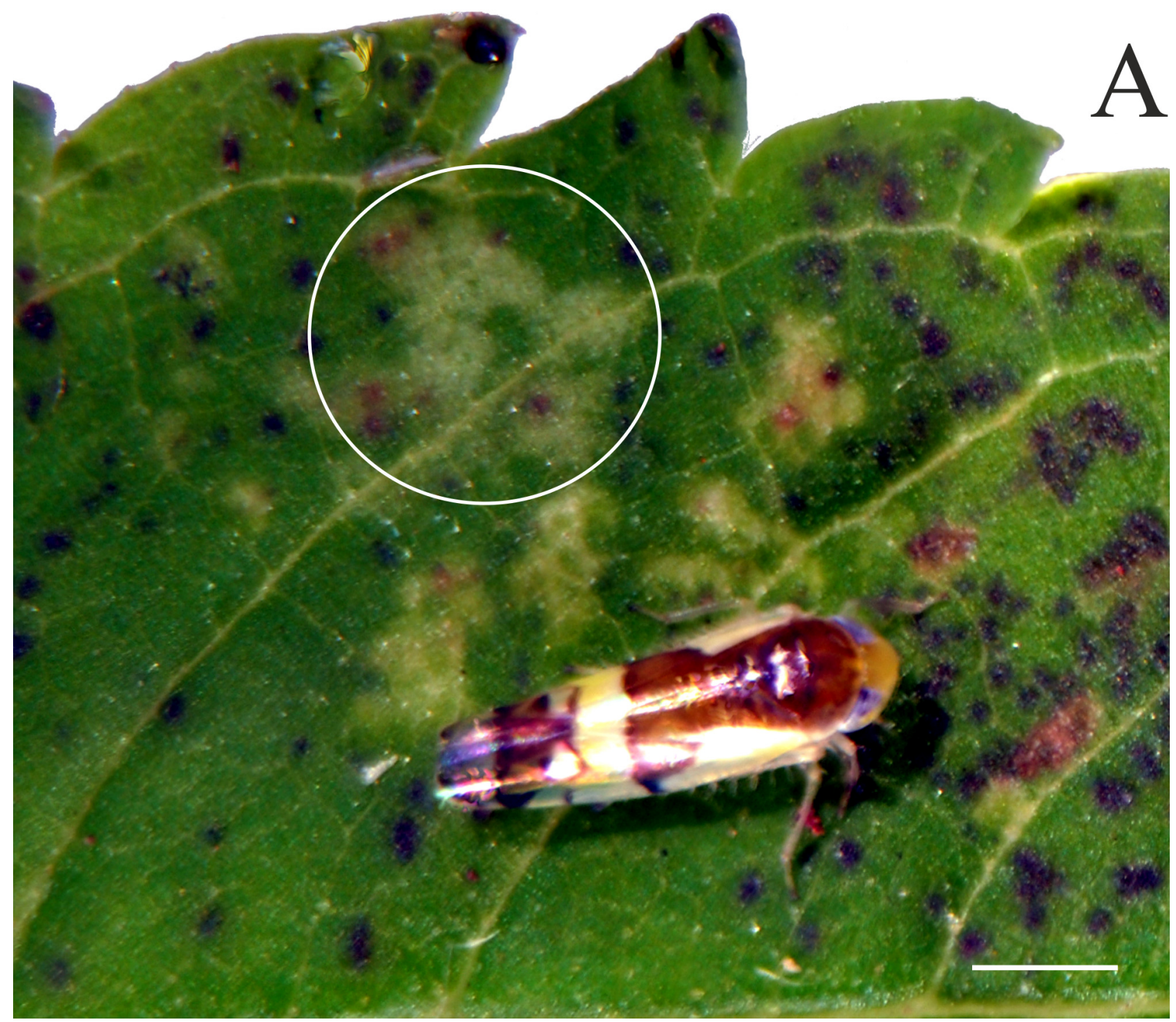

FIGURE 3. A. Damage by Rhabdotalebra albinoi n.sp. (Circle indicating the damage in the form of rings and horseshoes on leaves of "Guarán-Guarán”). Scale bar=1mm.

Seventh sternum (Fig.2A) subrectangular, posterior margin with short rounded median lobe. Pygofer (Fig.2B) in lateral view, with group of six or seven macrosetae on medioventral margin and six to eight macrosetae on dorsocaudal margin, dorsocaudal apex with one dark sclerotized and prominent spine. Valves of the ovipositor exceeding pygofer (Fig.2B, D). Second valvulae leaflike in third apical, very similar to $R$. litoralensis, but without teeth. Large valve (Fig.2C) dorsal margin and apex without teeth, with 2-3 sclerotized longitudinal bars of different size on surface, branched towards dorsal margin. Small valve (Fig.2C) similar, without teeth.

Type material. Holotype male, ARGENTINA: Buenos Aires, La Plata S $34^{\circ} 55^{\prime}$ and W 57 57', 28-xi-16, on Tecoma stans (L.) (Guarán-Guarán), Petrulevičius col. Paratypes: 2 male, 2 female, same collection date as the holotype.

Other material examined. 5 males, 4 females, La Plata, S $34^{\circ} 55^{\prime} \mathrm{W} 57^{\circ} 57^{\prime}$, 14-v-2012, on Tecoma stans (L) Juss. ex Kunth (“Guarán-Guarán”), Petrulevičius col., 1 female, La Plata, S $34^{\circ} 55^{\prime}$ W 57 57', 10-xi-2014, Petrulevičius col., 3 males, Temperley, S $34^{\circ} 46^{\prime}$ W 58 23', 8-9-vii-2012, on Tecoma stans (L.), Petrulevičius col., 1 female, La Plata, S 34 55' W 57 57', 23-ix-2016, on Tecoma stans (L.) "Guarán-Guarán”, Petrulevičius col.

Etymology. The new species is named for Prof. Albino M. Sakakibara in recognition of his outstanding contributions to knowledge of the fauna of South America.

Notes. $R$. albinoi n.sp. can be distinguished from the other known species of the genus by the following 
combination of features: Male (1) pygofer with ventral strongly sclerotized process, apex with two divergent strongly sclerotized and prominent dark spines, one long and other short, on posterodorsal margin. (2) Aedeagus with asymmetric apical and subapical processes directed caudoventrally. Female (3) pygofer with dorsocaudal apex with one dark sclerotized and prominent spine. Second valvulae leaflike in third apical, similar to $R$. litoralensis, but without teeth on dorsal margin and apex. The coloration pattern of the forewing is similar to that of $R$. litoralensis.

Biological notes (Fig.3A) R. albinoi n.sp. causes damage in the form of rings and horseshoes in high concentration, producing stippling on the leaves of "Guarán-Guarán".

\section{Acknowledgments}

Our thanks to Dr. Dietrich and Zootaxa coeditors for the invitation to participate in this special issue in honor of Dr. Sakakibara. This research was supported in part by Grant 11N/723 from UNLP, Argentina, financial support to S. Paradell and M. Inés Catalano from Comisión de Investigaciones Científicas (CIC) and to J. Petrulevičius by Consejo Nacional de Investigaciones Científicas y Tecnológicas (CONICET), Argentina.

\section{References}

Alonso, J. (2000) El Lapacho. Revista de Fitoterapia, 1 (2), 107-117.

Balduf, W. (1934) The taxonomic value of ovipositors in some Empoasca species (Homoptera, Cicadellidae), Annals of Entomological Society of America, 27, 293-310. https://doi.org/10.1093/aesa/27.2.293

Catalano, M.I., Paradell, S. \& Marino de Remes Lenicov A.M. (2010) Revision of the genus Rhabdotalebra Young (Hemiptera: Cicadellidae: Typhlocybinae: Alebrini) and description of two new species from Argentina, Zootaxa, 2601 (53), 53-60.

Catalano, M.I. (2011) "Cicadélidos vectores de fitoplasmas a cultivos de importancia económica en la Argentina. Sistemática y bioecología. (Insecta-Auchenorrhyncha-Cicadellidae)”.Tesis Doctoral. Facultad de Ciencias Naturales y Museo. Universidad Nacional de La Plata, Buenos Aires, 133 pp. Available from: http://sedici.unlp.edu.ar/bitstream/handle/ 10915/5330/Documento_completo.pdf?sequence=1 (Accessed 21 Jun. 2017)

Dietrich, C. (2005) Keys to the families of Cicadomorpha and subfamilies and tribes of Cicadellidae (Hemiptera: Auchenorrhyncha), Florida Entomologist, 88, 502-517. https://doi.org/10.1653/0015-4040(2005)88[502:KTTFOC]2.0.CO;2

Dietrich, C. (2013) Overview of the phylogeny, taxonomy and diversity of the leafhopper (Hemiptera: Auchenorrhyncha: Ciacadomorpha: Membracoidea: Cicadellidae). Vectors and Plant Pathogens. Proccedings of the 2013 International Symposium on Insect Vectors and Insect-Borne Diseases, 2013, pp. 47-70.

Dworakowska, I. (1994) Some Alebrini of Western Hemisphere (Insecta-Auchenorrhyncha-Cicadellidae- Typhlocybinae) Entomologische Abhandlungen Staatliches Museum für Tierkunde Dresden, 56 (I), 1-30.

Hadley, A. (2011) Combine ZP-Free image stacking software for depth of field correction. Available from: http:// www.hadleyweb.pwp.blueyonder.co.uk/CZM/combinezm.htm (accessed 15 September 2016)

Oman, P., Knight, W. \& Nielson, M. (1990) Leafhoppers (Cicadellidae): a bibliography, generic check-list and index to the world literature 1956-1985. CAB International Institute of Entomology, Wallingford, $368 \mathrm{pp}$.

Petrulevicius, J., Varela, A, Iglesias, A., Zamuner, A. \& Poiré D. (2014) First Cenomanian record of insects in the Southern Hemisphere, with Perforissidae (Fulgoroidea) and Cupedidae (Coleoptera) from Southern Patagonia, Argentina. Cretaceous Research, 51, 174-185. https://doi.org/10.1016/j.cretres.2014.05.016

Southern, P. (1982) A taxonomic study of the Leafhopper Genus Empoasca (Homoptera: Cicadellidae) in Eastern Peru. The North Carolina Agricultural Research Service. Technical Bulletin, 272, 1-194.

Young, D.A. Jr. (1952) A reclassification of Western Hemisphere Typhlocybinae (Homoptera, Cicadellidae). Kansas University Science Bulletin, 35, 1-217.

Young, D.A. Jr. (1957) The leafhopper tribe Alebrini (Homoptera, Cicadellidae). Proceedings of the United States National Museum, 107, 1-277.

https://doi.org/10.5479/si.00963801.107-3386.127 